\title{
Drosophila suzukii in Southern Neotropical Region: Current Status and Future Perspectives
}

\author{
F Andreazza ${ }^{1}$, D Bernardi ${ }^{2}$, RSS dos Santos ${ }^{3}$, FrM Garcia $^{4}$, Ee Oliveira ${ }^{1}$, M Botton $^{3}$, De Nava ${ }^{5}$ \\ ${ }^{1}$ Depto de Entomologia, Univ Federal de Viçosa, Viçosa, MG, Brasil \\ ${ }^{2}$ Depto de Fitossanidade, Univ Federal de Pelotas, Capão do Leão, RS, Brasil \\ ${ }^{3}$ Lab de Entomologia, Embrapa Uva e Vinho, Bento Gonçalves, RS, Brasil \\ ${ }^{4}$ Programa de Pós-graduação em Entomologia, Instituto de Biologia, Univ Federal de Pelotas, Capão do Leão, RS, Brasil \\ ${ }^{5}$ Lab de Entomologia, Embrapa Clima Temperado, Pelotas, RS, Brasil
}

\section{Keywords}

Spotted wing drosophila, area-wide integrated pest management, pest control, alien pest invasions

\section{Correspondence}

F Andreazza, Depto de Entomologia, Univ Federal de Viçosa, Av. Peter Henry Rolfs $\mathrm{s} / \mathrm{n}$ 36570 - 900, Viçosa, MG, Brasil; felipe. andreazza@ufv.br

Edited by Lessando Moreira Gontijo - UFV

Received 24 April 2017 and accepted 7 August 2017

(C) Sociedade Entomológica do Brasil 2017

\begin{abstract}
Non-native insect pests are often responsible for important damage to native and agricultural plant hosts. Since Drosophila suzukii Matsumura (Diptera: Drosophilidae) has become an important pest in North America and Europe (i.e., in 2008), the global production of soft thin-skinned fruits has faced severe production losses. In the southern Neotropical region, however, the first record of $D$. suzukii occurred in 2013 in the south of Brazil. It has also been recorded in Uruguay, Argentina, and Chile. Despite its recent occurrence in the southern Neotropical region, the fast dispersion of $D$. suzukii has inspired local research efforts in an attempt to mitigate the consequences of this insect pest invasion. In this forum, we explore the current status of $D$. suzukii in southern Neotropical regions, discussing its future perspectives. Additionally, we attempt to draft activities and a research agenda that may help to mitigate the losses caused by $D$. suzukii in native and commercial soft-skinned fruits produced in this region. Currently, D. suzukii appears to be well established in the south of Brazil, but considering the entire southern Neotropical region, the invasion panorama is still underinvestigated. The lack of studies and regulatory actions against $D$. suzukii has contributed to the invasion success of this species in this region. Considering several peculiarities of both the pest biology and the environmental of this region, the authors advocate for the need of intensive and integrative studies toward the development and implementation of area-wide integrated pest management programs against $D$. suzukii in the southern Neotropical region.
\end{abstract}

\section{Introduction}

Historically, alien pest invasions usually result in severe production losses due to economic, social, and health damage (Jackson \& Lee 1985, Benedict et al 2007, Desneux et al 2011, Asplen et al 2015, Kriticos et al 2015, Singer 2017). The final scenario for pest establishment as well as the number of necessary efforts to mitigate the environmental disturbances caused by the pest has been a persistent question (Perrings et al 2002, Desneux et al 2011, Asplen et al 2015). However, early studies predicting all possible aspects of local interactions of the alien species with known or other potential hosts, pest competitiveness with the native species and susceptibility to endemic natural enemies can greatly aid the organization and development of the most adequate management plans (Cini et al 2012, Asplen et al 2015, Kriticos et al 2015). It is, however, worth noting that the use of current knowledge 
obtained in areas previously invaded by the alien pest will also help to organize and plan such efforts.

Although Zaprionus indianus Gupta (Diptera: Drosophilidae) has been well established as an important insect pest of the fig, Ficus carica L. (Moraceae), in Brazil (Raga et al 2003), Drosophila suzukii Matsumura (Diptera: Drosophilidae), also termed the spotted wing drosophila (SWD) or the cherry fly, has achieved the status of one the most important newly emerged insect pests of small softskinned fruits (Walsh et al 2011, Asplen et al 2015). Drosophila suzukii is a devastating, highly polyphagous fly that is native to Southeast Asia (Asplen et al 2015); it was described in 1931 by Matsumura, but this insect was first reported as a pest in 1939 by Kanzawa in Japan (Hauser 2011). The damage caused by these insects, however, only gained global attention after almost simultaneous reports of their damage to soft and thin-skinned fruit crops in the USA (Hauser 2011) and Europe (many countries) (Grassi et al 2009, Calabria et al 2012). Since then, many features of the bioecological roles of $D$. suzukii as well as its interactions with the production system have being intensively studied in an attempt to mitigate the economic loses in cultivated crops in North America and Europe [see Asplen et al (2015) for a more complete review].

In contrast to most drosophilid species (Drosophilidae), $D$. suzukii females have a serrated and strongly sclerotized oviscapt valves that allows them to penetrate the fruit epidermis and lay their eggs inside healthy undamaged fruits (Dreves et al 2009, Walsh et al 2011, Santos 2014, Lee et al 2015, Nava et al 2015). After the female lays its eggs, over a very short period from 1 to 2 days, the eggs hatch and the larvae start to feed on the fruit tissue (Walsh et al 2011). After three molts, the larvae become pupae, from which the adults emerge. At an average temperature of $22^{\circ} \mathrm{C}$, this development takes approximately 11 days, followed by 1 to 2 additional days for the adult flies to become sexually mature, copulate, and start laying eggs (Emiljanowicz et al 2014, Tochen et al 2014, Asplen et al 2015). Hence, in approximately 13-14 days, a new fly generation is laying eggs. The adults can live, on average, up to 70 days, and they show a high reproductive output (Emiljanowicz et al 2014).

Thus, due to the high damage potential of $D$. suzukii in addition to the lack of registered pesticides and other regulatory means for controlling the dispersion of these flies in the southern Neotropical region, it is quite interesting to report the seminal efforts already applied to recognize the current status and future perspectives involving this pest in the southern Neotropical region, which herein refers to Uruguay, Argentina, Chile, and the South, Southeast, and Central regions of Brazil. Here, we will present current and future potential damage caused by $D$. suzukii in both native and commercial thin-skinned fruits cultivated in the southern Neotropical region. Finally, we will also propose future studies and potential programs to better manage this insect pest in this region.

\section{Current Pest Status in the Southern Neotropical Region}

Invasion history and current distribution

In Central and South America, which comprise the majority of the Neotropical region, the first record of $D$. suzukii was a personal communication (of P. M. O'Grady to M. Ashburner and to J. Máca) of specimens collected in Costa Rica and Ecuador in 1997 and 1998, respectively (Ashburner et al 2005, Calabria et al 2012). However, up to the year of 2010, such specimens were not found in any insect collection, and this species had not been recorded again in those countries. Thus, it is difficult to estimate when these flies arrived in the Neotropical regions (Hauser 2011). In addition to the inconclusive report described above, it is reasonable to consider the current distribution of $D$. suzukii in the southern of the Neotropical region (see Fig 1) to have started with invasive infestations that occurred via two possibilities. First, one potential route used to enter the southern Neotropical region refers to the southern region of Brazil, which had the

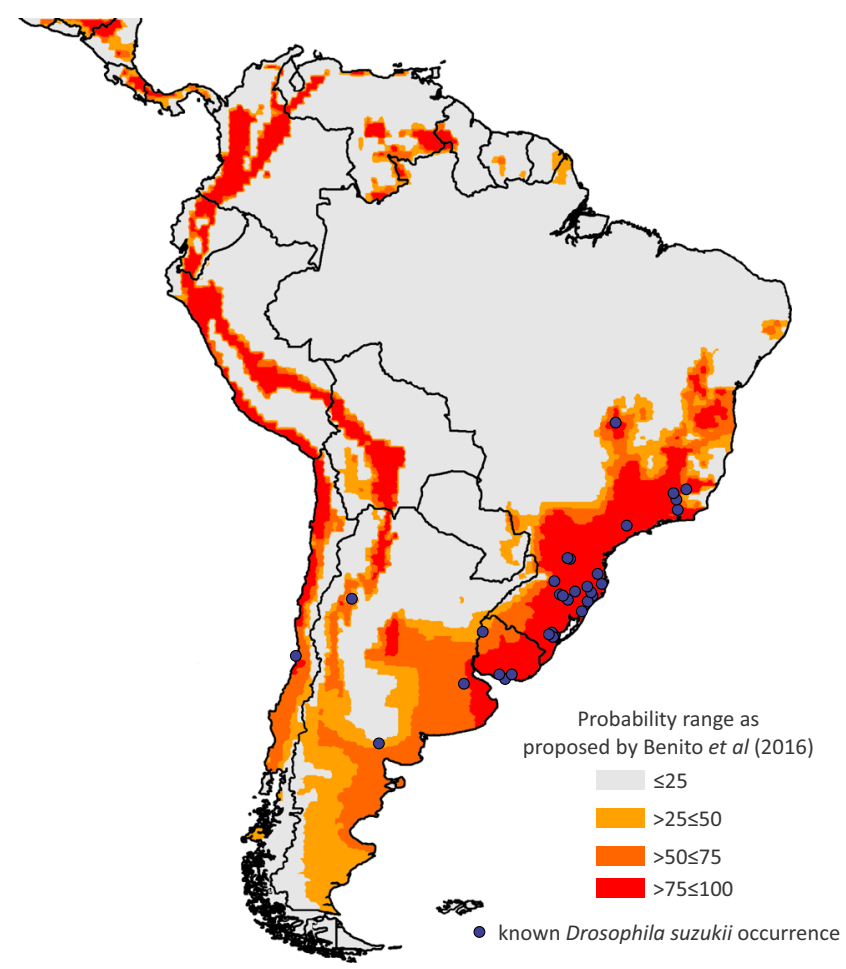

Fig 1 Graphical representation of part of the Neotropical region with the known Drosophila suzukii occurrence map overlapping the distribution probability range for this species, as proposed by Benito et al (2016). All plotted dots are based on references listed in Table 1, or on the author's personal observations/unpublished data. 
first documented report of this pest in South America (Deprá et al 2014). The second possibility, however, points to the Pacific coast of Chile, where the species were collected around Valparaíso port, which imports a variety of fresh fruits from Asia (Medina-Muñoz et al 2015). To clarify whether these two not mutually exclusive possibilities (or even others) could precisely define the real origin of $D$. suzukii in the southern Neotropical region, it is necessary to conduct genetic and philogeographical analyses. Table 1 summarizes all the published records of $D$. suzukii in the southern Neotropical region. Because one the most relevant goals of this forum is to report all existing information about the occurrence of $D$. suzukii and early researches with this pest in the southern Neotropical region, we could not avoid the citation of reports that have only been published in congresses or symposium abstract form.

In Brazil, during the first year of the occurrence of D. suzukii (i.e., 2013), the individuals were only collected in traps located in natural reserves (Souza et al 2013, Deprá et al 2014, Paula et al 2014). The D. suzukii individuals were collected in a drosophilid survey using bananabaited traps at a natural reserve in the state of Santa Catarina (SC). Two months later, the same survey program revealed $D$. suzukii in the northeast region of the state of Rio Grande do Sul (RS) (Deprá et al 2014). Later, during that year, D. suzukii was collected in apple cider vinegar traps placed in a natural forest area in the southern region of RS state (Souza et al 2013). In 2013, one D. suzukii male was captured in a banana-baited trap in the central region of Brazil in a natural Cerrado (savannah-like vegetation) reserve at the Brazilian Federal (DF) district (Paula et al 2014). Subsequently, in 2014, D. suzukii was reported in agricultural ecosystems, either collected in McPhail traps (Nunes et al 2014) or infesting native cultivated fruits (Müller \& Nava 2014, Nunes et al 2014) in the southern region of RS state. Following these first reports, strawberry, Fragaria $x$ ananassa Duchesne (Rosaceae), producers from the northeast of RS state started to experience fruit losses of up to $30 \%$ due to infestations by this fly (Santos 2014). The presence of $D$. suzukii in the state of Paraná was also reported by Geisler et al (2015). Collectively, these findings allow us to state that $D$. suzukii is currently distributed and well established throughout the entire southern region of Brazil (Fig 1).

Outside the southern region of Brazil, D. suzukii was reported in 2014 in the São Paulo municipality, São Paulo state (SP), developing in marketed blueberry fruits that were produced in the municipality of São Joaquin, SC state (Vilela \& Mori 2014). Furthermore, D. suzukii was also collected in traps placed in a native Atlantic Rainforest in the state of Rio de Janeiro (RJ) (Bitner-Mathé et al 2014) and from strawberry fields in the state of Minas Gerais (MG) (Andreazza et al 2016a).
In Uruguay and Argentina, D. suzukii was found infesting blueberries, Vaccinium ashei Reade (Ericaceae), and raspberries, Rubus idaeus L. (Rosaceae) (Cichón et al 2015, González et al 2015, Santadino et al 2015), but in Uruguay it was also found in traps in the urban area of Montevideo city (González et al 2015). In Chile, there has only been one report of this species, which was collected from traps near the Valparaiso Port (Medina-Muñoz et al 2015).

\section{Damage ability and cultivated hosts in the Southern Neotropical Region}

Currently, the main cultivated host that is susceptible to severe economic losses in the southern Neotropical region is strawberries, which have been shown to achieve production losses up to 30\% (Santos 2014). However, other common non-native cultivated soft and thin-skinned fruits, such as blueberries, as well as native fruits such as the Surinam cherry, Eugenia uniflora L. (Myrtaceae), and Cattley guava, Psidium cattleyanum Sabine (Myrtaceae) (Fig 2), have been reported under high levels of natural infestations (Müller \& Nava 2014, Santadino et al 2015).

The southern Neotropical region exhibits a high overlap of environmental conditions with the northern hemisphere, where $D$. suzukii is well established (Kenis et al 2016). Hence, many of the crops cultivated in the southern Neotropical region are known as hosts of $D$. suzukii. This is the case for blackberries [Rubus sp. (Rosaceae)], blueberries, cherries [Prunus cerasus L. (Rosaceae)], grapes [Vitis vinifera L. (Vitaceae)], peaches [Prunus persica (L.) Batsch (Rosaceae)], plums [Prunus domestica L. (Rosaceae)], raspberries, and strawberries. In addition to the similarity of the cultivated hosts, the southern region of Brazil, as well as Uruguay and part of Argentina, has a highly favorable Climex (a common model used to predict the potential geographic distribution of alien pest species), which increases the economic damage potential of this pest (Benito et al. 2016). These authors observed percentages of overlap between potential host cultivation and the highly favorable Climex area they defined for $D$. suzukii, which ranged from 45.5 to $98.3 \%$ for six potential cultivated hosts. The same authors estimated monetary economic loses of US\$ 21.4 million for peaches and US\$ 7.8 million for figs, but they could not estimate losses for the other hosts due to the lack of data.

It is important to note that, at least for some peach cultivars, $D$. suzukii displays very low oviposition on undamaged fruits but can use damaged fruits as a reservoir host (Andreazza et al 2017a). The same pattern has been observed during infestation of the apple, Malus domestica L. (Rosaceae), in which prior damage is necessary for D. suzukii oviposition to occur (Oliveira et al 2015). 


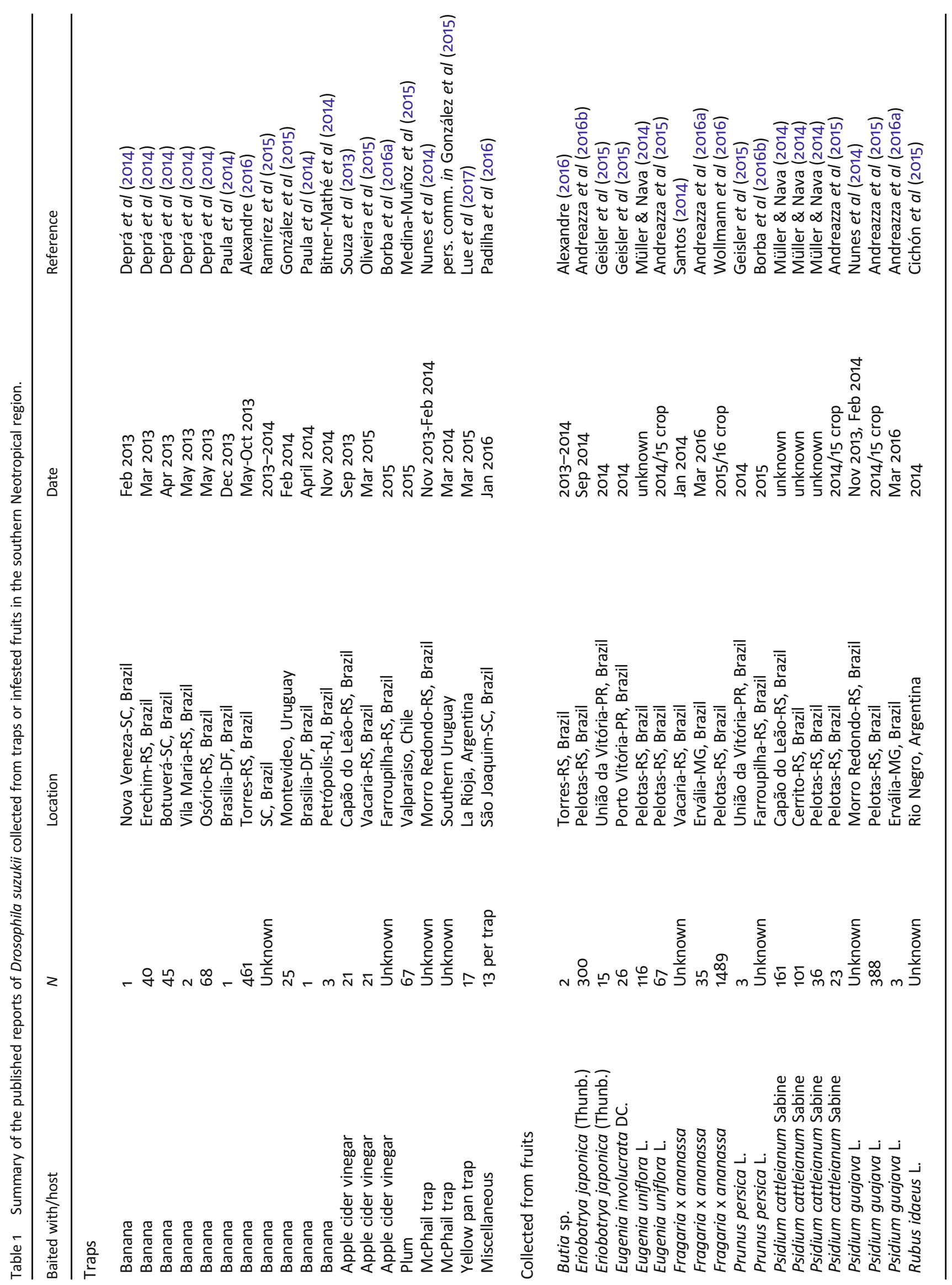




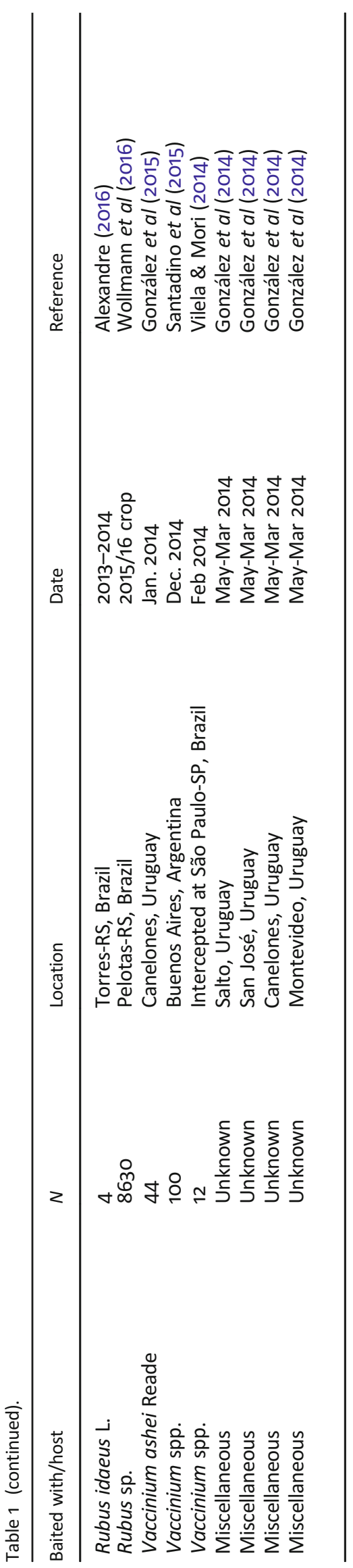

Among other factors that might increase or suppress the pest potential of this species in South America is the ability to interact with fruits that have been damaged by other pest species, as is the case for the introduced and well-established African fig fly, Z. indianus (Commar et al 2012), and the native South American fruit fly, Anastrepha fraterculus (Wiedemann) (Diptera: Tephritidae) (Malavasi \& Zucchi 2000). In strawberry fields, drosophilid-like larval damage appears to result in increased effects of $Z$. indianus compared with D. suzukii (Nava et al 2015, Andreazza et al 2016a).

In a recent survey (2016-2017) in three municipalities of MG state, larger numbers of $Z$. indianus compared with D. suzukii (12.9 vs $0.2 ; 4.8$ vs 0.0 and 0.2 vs 0.04 , flies per fruit) were harvested from strawberry fruits with very low visual damage (author's unpublished data). The potential interactions between these two species have also been established elsewhere (Renkema et al 2013, Fartyal et al. 2014, Joshi et al 2014, Lasa \& Tadeo 2015), highlighting the hypothesis that the co-occurrence of these pest species can increase the damage and economic losses in strawberry production and potentially other fruit crops. For example, although $Z$. indianus is known to be incapable of laying eggs inside healthy undamaged fruits, (Raga et al 2003), a recent investigation has revealed not only the ability of $Z$. indianus to infest undamaged strawberry fruits but also the increased infestation ability when the fruits were previously infested by D. suzukii (Bernardi et al 2017).

In contrast, the presence of $A$. fraterculus might reduce the damage potential of $D$. suzukii infestations, or it may not influence the $D$. suzukii attack capacity. In a susceptibility screening study using grape cultivars, the presence of oviposition punctures or of the development of $A$. fraterculus larvae did not induce D. suzukii oviposition (Andreazza et al 2016c). Additionally, $A$. fraterculus intrinsically infests fruits before they reach an advanced ripening stage (Bisognin et al 2015), which seems to be the preferable stages for $D$. suzukii infestations (Burrack et al 2013). Thus, depending on the market fruit destination and the $A$. fraterculus infestation intensity, it would be sufficient to cause the major economic loses, reducing the importance of $D$. suzukii infestation.

The abilities of $D$. suzukii to infest damaged fruits can turn less preferred hosts (e.g., peaches) into highly infested sites (Bellamy et al 2013, Andreazza et al 2017a), which might result in more severe infestations in preferred hosts that are cultivated nearby. Consequently, the role of previously damaged or less preferred hosts, as well as the native fruit species, must never be disregarded when considering the management of this pest.

\section{Potential native hosts}

As previously reported in Europe and North America (Poyet et al 2014, Lee et al 2015), D. suzukii can infest many native non-cropping hosts. Countries with continental proportions, 


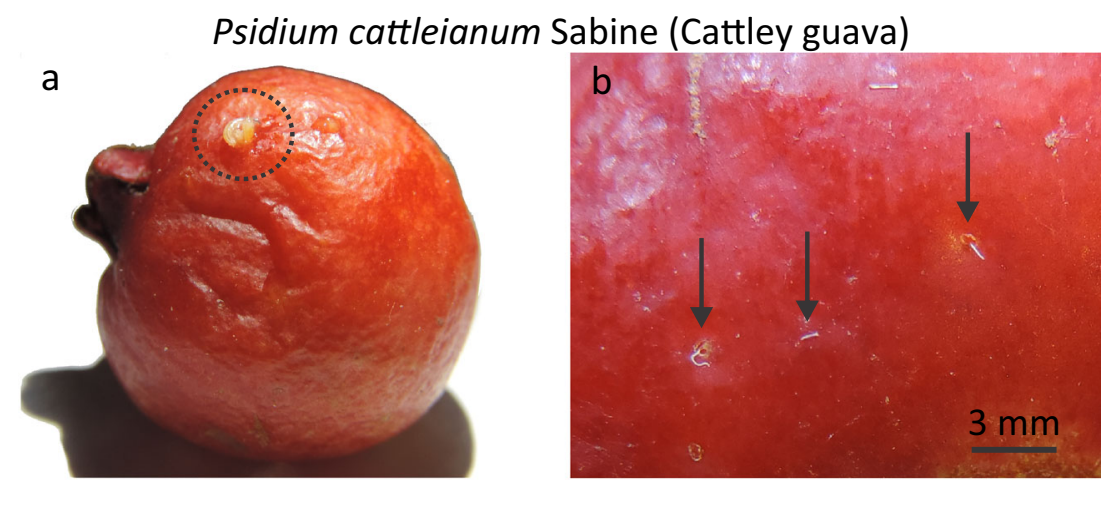

Fig 2 Drosophila suzukii damage in two Neotropical native hosts. a-b Fruit of Cattley guava, Psidium cattleianum. c- $\mathbf{d}$ Fruit of Surinam Cherry, Eugenia uniflora. In (a), it is possible to see a D. suzukii larva on the fruit surface (dotted circle). b, d White egg filaments emerging from the oviposition punctures made by D. suzukii (black arrows).

Eugenia uniflora L. (Surinam cherry)
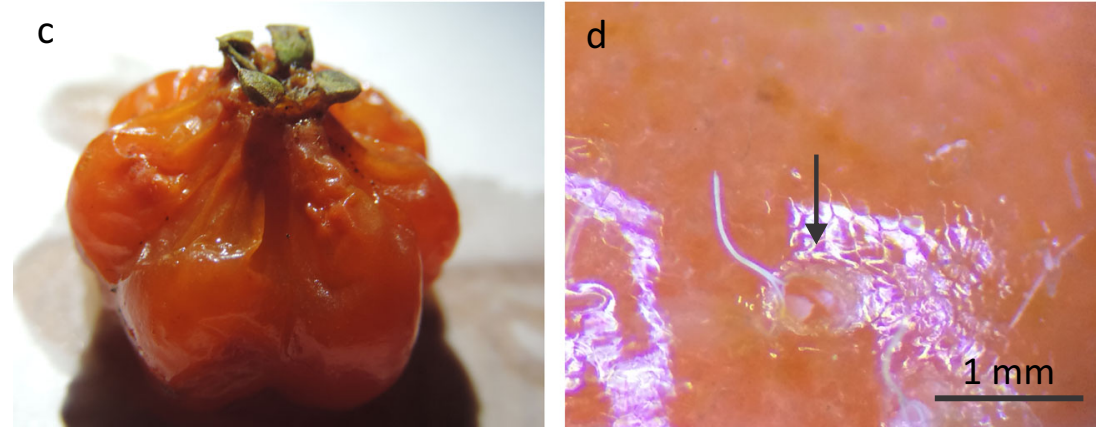

such as Brazil, offer the most varied climate types and plant hosts for $D$. suzukii infestations. Several native (and also exotic) fruits can offer conditions for the development and establishment of $D$. suzukii, which raise serious concerns about how and when mitigate the losses caused by this pest (Schlesener et al 2014, Schlesener et al 2015). Although it is not a native plant of the southern region of Brazil, the Loquat, Eriobotrya japonica (Thumb.) Lindley (Rosaceae), another $D$. suzukii host (Kenis et al 2016) is well established and naturally found among the native vegetation in the south of Brazil. As described in Table 1, several recent investigations have demonstrated the ability of $D$. suzukii to attack fruit species native to the southern Neotropical region (Müller \& Nava 2014, Nunes et al 2014, Andreazza et al 2015, Geisler et al 2015, Souza et al 2017).

Thus, additional studies attempting to investigate the susceptibility of native plant species to the oviposition of $D$. suzukii (Table 2) are sorely needed. This study will provide a better understanding of $D$. suzukii establishment in the southern Neotropical region and help to predict geographic isolation due to lack of suitable hosts. Furthermore, knowledge of possible alternative hosts can help to create an annual host calendar (as shown in Fig 3), which will facilitate temporal predictions of how $D$. suzukii migrates from and returns to the surrounding natural or agricultural habitats to the fields.

\section{Management strategies}

Since $D$. suzukii has a very short life cycle, a long adult lifespan and a high reproductive output (Emiljanowicz et al
2014, Tochen et al 2014), management strategies must target both immature and adult life stages of this pest. Most of the management programs established for D. suzukii worldwide, however, still rely heavily on applications of chemical insecticides (Haye et al 2016), especially in regions with zero tolerance for this pest, such as some states in the USA (Van Timmeren \& Isaacs 2013). Thus, many research efforts have been conducted to evaluate the efficacy of several commercially available insecticides in North America and Europe, which has led to the identification of several chemical groups that provide satisfactory control levels (Beers et al 2011, Bruck et al 2011, Haviland \& Beers 2012, Van Timmeren \& Isaacs 2013, Cuthbertson et al 2014). However, despite recent investigations showing that some commercially available products in Brazil provide effective control against immature and adult life stages of $D$. suzukii (Andreazza et al 2017c), none of these products is officially registered by the Brazilian federal control agencies against D. suzukii (MAPA 2016). Similar situations are observed in Uruguay (MGAPServicios Agrícolas 2017) and Chile (SAG 2017). For Argentina, there is still, to our knowledge, no available information regarding the official registration of synthetic insecticides against $D$. suzukii.

The lack of registered products has not reduced the use of other management strategies. The use of good agricultural practices (i.e., field sanitization) is the major key for the success of D. suzukii management (Nava et al 2015, Haye et al 2016). Since the period from egg to adult is very short, harvesting fruits over shorter intervals and eliminating 
Table 2 Confirmed and potential host plants for Drosophila suzukii in the southern Neotropical region.

\begin{tabular}{|c|c|c|}
\hline Scientific name & Family name & Common name \\
\hline \multicolumn{3}{|l|}{ Confirmed exotic cultivated hosts ${ }^{\mathrm{a}}$} \\
\hline Actinidia chinensis Planch. & Áctinidiaceae & Kiwi \\
\hline Diospyros kaki Thunberg & Ebenaceae & Kaki \\
\hline Eriobotrya japonica (Thunb.) Lindl. $\checkmark$ & Rosaceae & Loquat \\
\hline Ficus carica $\mathrm{L}$. & Moraceae & Figs \\
\hline Fragaria $\mathrm{x}$ ananassa Duchesne $\checkmark$ & Rosaceae & Strawberry \\
\hline Malus domestica L. & Rosaceae & Apple \\
\hline Morus spp. & Moraceae & Mulberry \\
\hline Prunus armeniaca $\mathrm{L}$. & Rosaceae & Apricot \\
\hline Prunus avium L. $\checkmark$ & Rosaceae & Sweet cherry \\
\hline Prunus domestica L. $\checkmark$ & Rosaceae & Common plum \\
\hline Pyrus communis L. & Rosaceae & European pear \\
\hline Pyrus pyrifolia (Burm.) Nak. & Rosaceae & Asian pear \\
\hline Rubus fruticosus L. $\checkmark$ & Rosaceae & Blackberry \\
\hline Rubus idaeus L. $\checkmark$ & Rosaceae & Raspberry \\
\hline Vaccinium spp. $\checkmark$ & Ericaceae & Blueberries \\
\hline Vitis labrusca & Vitaceae & Fox grape \\
\hline Vitis vinifera L. & Vitaceae & Grape vine \\
\hline
\end{tabular}

Confirmed native hosts ${ }^{\mathrm{ab}}$

$\begin{array}{lll}\text { Acca sellowiana (O.Berg) Burret } & \text { Myrtaceae } & \text { Feijoa } \\ \text { Butia } \text { spp. } & \text { Arecaceae } & \text { Butiá (a type of palm tree) } \\ \text { Eugenia involucrata DC. } & \text { Myrtaceae } & \text { Cherry of Rio Grande } \\ \text { Eugenia uniflora } \text { L. } \checkmark & \text { Myrtaceae } & \text { Surinam cherry } \\ \text { Prunus serotina } \text { Ehrhart } & \text { Rosaceae } & \text { Wild black cherry } \\ \text { Psidium cattleianum Sabine } \checkmark & \text { Myrtaceae } & \text { Cattley guava } \\ \text { Psidium guajava } \text { L. } & \text { Myrtaceae } & \text { Common guava }\end{array}$

\section{Potential native hosts ${ }^{b}$}

Allophylus edulis (A St.Hil.) Radilk.

Campomanesia guazumifolia (Camb.) Berg.

Campomanesia phaea (Berg) Landrum

Campomanesia pubescens (Aubl.) Griseb.

Campomanesia xanthocarpa $\mathrm{O}$. Berg

Eugenia brasiliensis Lam.

Eugenia candolleana DC.

Eugenia guabiju O.Berg

Eugenia mattosii D.Legrand

Eugenia subterminalis DC.

Eugenia uvalha Cambess.

Garcinia gardneriana Mart.

Myrciaria cuspidata Berg in Mart.

Myrciaria glazioviana Kiaersk

Odontocarya acuparata Miers

Plinia aureana (Mattos)

Plinia cauliflora (Mart.) Kausel

Plinia edulis (Vell.) Sobral

$\begin{array}{ll}\text { Sapindaceae } & \text { Chal-chal } \\ \text { Myrtaceae } & \text { Sete-Capotes } \\ \text { Myrtaceae } & \text { Cambuci } \\ \text { Myrtaceae } & \text { Guabiroba } \\ \text { Myrtaceae } & \text { Guabiroba } \\ \text { Myrtaceae } & \text { Grumixama } \\ \text { Myrtaceae } & \text { Cambuí } \\ \text { Myrtaceae } & \text { Guabijú } \\ \text { Myrtaceae } & \text { Cereja anã } \\ \text { Myrtaceae } & \text { Cambuí-Pitanga } \\ \text { Myrtaceae } & \text { Uvaia } \\ \text { Clusiaceae } & \text { Bacupari } \\ \text { Myrtaceae } & \text { Cambuí } \\ \text { Myrtaceae } & \text { Jabuticaba-amarela } \\ \text { Menispermaceae } & \text { Capeba } \\ \text { Myrtaceae } & \text { Jabuticaba-branca } \\ \text { Myrtaceae } & \text { Jabuticaba } \\ \text { Myrtaceae } & \text { Cambucá }\end{array}$

The host status was based on: Cini et al (2012), Bellamy et al (2013), Asplen et al (2015), Lee et al (2015), Kenis et al (2016), Souza et al (2017).

${ }^{a} \checkmark=$ Preferred host.

${ }^{\mathrm{b}}$ All hosts are native in south and/or southeast Brazil, and some are native also in Uruguay and Argentina. The authors did not include plant species from Chile in this suggested list. 


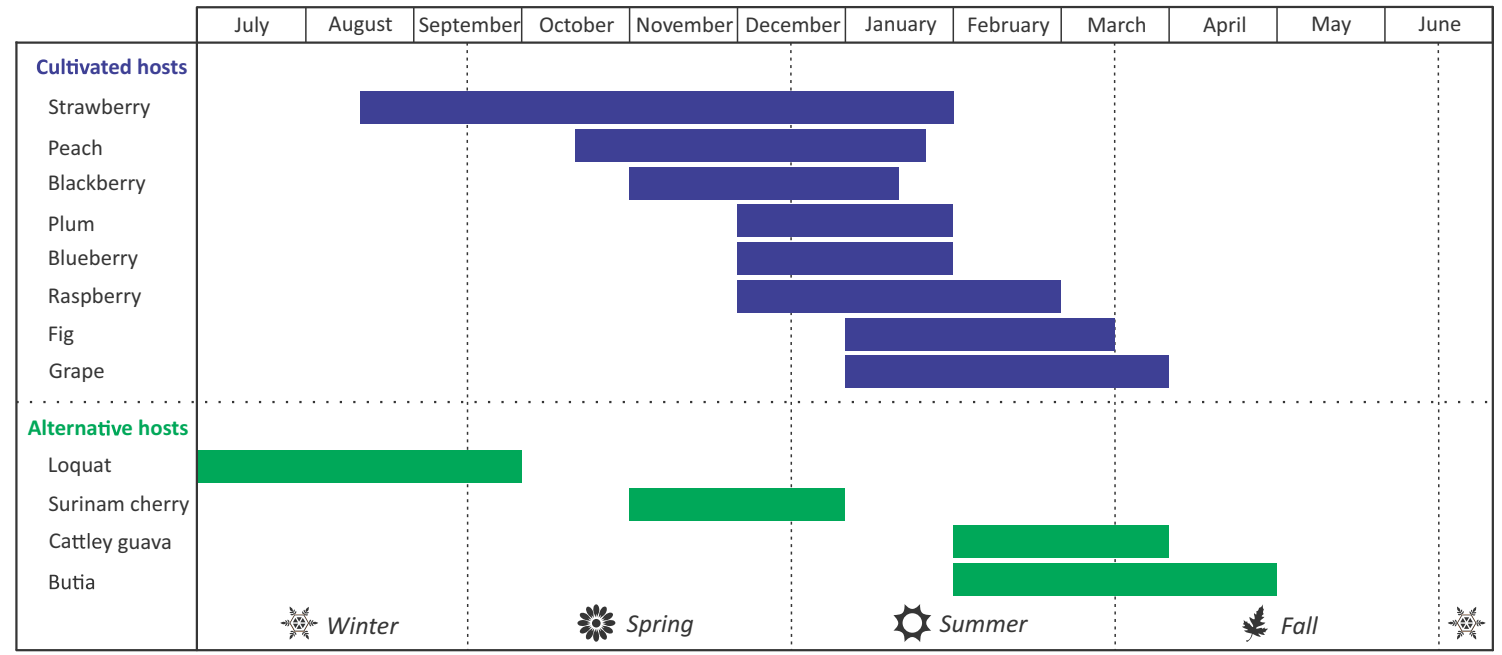

Fig 3 Proposed annual calendar showing the availability of Drosophila suzukii hosts in suitable stage (bars) (ripe fruits-near harvest) in the macroregion of Pelotas-RS, Brazil. The host phenology was based on: Bianchi et al (1998), Raseira et al (2004), Antunes et al (2008), Castro (2008), Madail \& Raseira (2008), Azambuja (2009), Azevedo (2010), Cardoso et al (2012), Carvalho (2013), Bisognin et al (2015). See Table 2 for the host's scientific names.

(destroying) any damaged fruit can partially prevent the development of new adults in the field. Pruning fruit trees or removing dead leaves from strawberries (Nava et al 2015), as well as managing intercropping weeds, promote less favorable environments for this pest, which prefers a humid microhabitat and a mild temperature (Tochen et al 2014, Tochen et al 2016).

One effective, but costly, strategy is the use of netting to cover the plants, preventing the contact of flies with the fruits (Nava et al 2015). In some countries in Europe, the use of netting associated with mass trapping and chemical insecticides has been shown to be effective against $D$. suzukii (Ioriatti et al 2015). In Brazil, where there are currently no quarantine actions or legal tolerance levels to be followed, the growers can legally manage their fields with a low and acceptable population level of the pest.

Finally, the use of biological agents to suppress $D$. suzukii has also been intensively investigated (Asplen et al 2015). There are reports of several parasitoids species attacking D. suzukii (Chabert et al 2012, Gabarra et al 2015, Daane et al 2016, Guerrieri et al 2016), and the application of pathogens such as nematodes and fungi are part of on-going efforts in many countries (Haye et al 2016). One of the most prospective parasitoid species is Trichopria drosophilae Perkins (Hymenoptera: Diapriidae), which presents high levels of pupal parasitism (Wang et al 2016) and could control $D$. suzukii in strawberry cultivated in greenhouses in Italy (Trottin et al 2014). In the southern Neotropical region, a closely related species, Trichopria anastrephae Lima (Hymenoptera: Diapriidae), and Leptopilina boulardi (Barbotin, Carton \& Kelner-Pillault) (Hymenoptera: Figitidae) were recently reported to attack $D$. suzukii pupae and larvae in strawberry and blackberry fields (Wollmann et al 2016). In the same region, T. anastrephae were also collected from strawberry fruits and mass reared in the laboratory on either pupae of $D$. suzukii or $Z$. indianus (Andreazza et $a / 2017 \mathrm{~b}$ ). These previous results are very important and provide a prospective for the development of both conservative and augmentative biological control in the southern Neotropical region.

\section{Future Perspectives}

\section{Potential distribution range: observations of Its dispersion} paths

The main factor that might limit future $D$. suzukii establishment in Brazil, as well as other parts of the southern Neotropical region, is the combination of adequate temperature and relative air humidity (Benito et al 2016). These factors were well discussed in their work, and their results are partially presented in Fig 1 . Furthermore, the availability of potential $D$. suzukii host plants is a relevant factor capable of impacting the distribution of $D$. suzukii in the Neotropical region. As shown in Table 2, several plant species can serve as potential hosts for $D$. suzukii. However, knowing that this species is highly polyphagous (Kenis et al 2016), we should expect a lack of some other potential hosts that are not listed in this table that can also expand the limits of the distribution and establishment of $D$. suzukii.

The application of adequate laws to regulate the fresh fruit trade market, not only among the regions proposed by Benito et al (2016), might be the most effective way to delay the arrival and establishment of $D$. suzukii in new areas. Some important considerations concerning the invasion 
history in the southern Neotropical region, as described earlier in the text, are helpful to understand the rapid spread of $D$. suzukii in this region.

In the same year that $D$. suzukii was first recorded in the south of Brazil (Deprá et al 2014), the species was also reported in a natural reserve approximately $1400 \mathrm{~km}$ north of that locality (Paula et al 2014). Although further investigations are needed to evaluate whether the single specimen collected in this second location is or is not related to the first ones, these two consecutive reports suggest the rapid dispersion capacity of $D$. suzukii. The infestation in Uruguay and Argentina are likely a consequence of the natural spread of this species after its introduction in the southernmost region of Brazil, especially due to the geographical proximity and absence of physical barriers. However, the hypothesis that the introduction of $D$. suzukii to these countries (i.e., Argentina and Uruguay) occurred through the fresh fruit trade market, either from Brazil or from other infested regions such as North America, Europe, or Asia, cannot be overlooked. This last hypothesis is strongly applicable to the case in Chile, where the fly was found only in traps near Valparaíso Port in Valparaiso city, which imports large amounts of fresh fruits, such as plums, from Asia (MedinaMuñoz et al 2015). These authors also highlighted that D. suzukii specimens present in this region of Chile had a strong preference for plum-baited traps instead of bananabaited traps, supporting the close relationship with this host.

The dispersion path through the fresh fruit trade market was also reported in Brazil in 2014, when blueberries grown in SC state had D. suzukii infestations at a fruit market in São Paulo city (Vilela Mori 2014). Another host that certainly provided means for the dispersion of this pest is the grape. In January 2017, a large number of $D$. suzukii flies were observed and collected in grapes being transported to a winery on a truck approximately $90 \mathrm{~km}$ from its growing location in RS state, Brazil (author's personal observation). Independently if the flies were the primary or secondary organisms infesting these grapes, according to the driver, a delivery of grapes from the same field would be performed the next day in a winery in SC state, which is approximately $250 \mathrm{~km}$ from the growing field. Even the Brazilian Ministry of Livestock and Supply is monitoring the presence of the species in some production regions (not in all states) (authors' personal information), the lack of further information about the presence of the pest and mitigation of regulatory means clearly contribute to the actual scenario of $D$. suzukii invasion.

Corroborating the predictions of Benito et al (2016), dos Santos et al (2017), based on climatic variables, mathematically predicted that the central region of southern Brazil, the southern half of Paraguay, all of Uruguay, and the east and south of Argentina are potential distribution areas for D. suzukii. On the Pacific coast, the entire coastline of Chile is indicated as a potential distribution area of this insect pest. The areas of greatest environmental suitability for $D$. suzukii are in southern Chile, Uruguay, on the south coast and in south Brazil, and along a small range on the northern coast of Argentina (dos Santos et al 2017).

\section{What to do to mitigate the problem}

According to current knowledge about $D$. suzukii bioecology in areas where this pest is already established (Asplen et al 2015), as well as the similarities of its interactions with hosts that have been damaged by some other well-known fruit fly pests (Diptera: Tephritidae), it is necessary to consider areawide (AW) integrated pest management (IPM) programs. The AW approach has also recently been recommended by research conducted in the Northern Hemisphere (Cini et al 2012, Asplen et al 2015, Haye et al 2016, Kenis et al 2016). The best way to cope with this pest is a well-integrated composite of actions by regulatory agencies, researchers, extension services, and growers, which can be a great challenge in some parts of the southern Neotropical region due to the cultural characteristics and historical experience of growers in terms of managing other native fruit fly species.

Unfortunately, D. suzukii has never been included in any quarantine list in Brazil (the authors have no information about Uruguay, Argentina and Chile), which would have alerted customs barriers and extension services to readily establish monitoring programs in the most susceptible areas, near ports and in areas with potential host plants. Nevertheless, regulatory actions are still needed and are very useful, especially to avoid continued reintroductions (Cini et al 2014) that could increase, for example, the source of insecticide resistance genes. Controlling fresh fruit trade market is essential since it has been suggested to be the main dispersion means of this pest worldwide (Cini et al 2014) as well as in the southern Neotropical region (Vilela \& Mori 2014, Medina-Muñoz et al 2015).

Another important action to be taken by the regulatory agencies and industries is the registration of insecticides and biological control agents for safe and legal use in the field. The lack of registered control agents can lead to an increase in the unregulated and illegal market of pesticides as well as its unsafe use in the field. In this respect, laboratory and field efficacy screening tests with products that have already been registered to manage other pests in $D$. suzukii cultivated hosts are sorely needed, which can reduce the amount of paperwork and time needed to obtain the product licenses. Some information regarding the synthetic insecticides used in Brazil is already available (Andreazza et al 2017c), but additional studies are still needed.

In addition to regulatory actions, the extension service must gather as much information as possible on the available D. suzukii management strategies [as in Nava et al (2015) and 
Haye et al (2016)] and work with the growers to delay this pest establishment in production fields. As discussed above, one of the main bottlenecks for the implementation of an AW-IPM for $D$. suzukii in the southern Neotropical region is the knowledge about the host suitability of native or noncultivated fruit plants, as reported by Diepenbrock et al (2016) and Kenis et al (2016). Finally, more field surveys for endemic parasitoid species, such as that conducted by Wollmann et al (2016), and the development of mass rearing techniques for these parasitoids (Andreazza et al 2017b) will support information to plan conservative and augmentative biological control programs in each macroregion of the southern Neotropical region.

In addition to the most common or traditional managements approaches, studies must also focus on products and strategies that cope with organic production regulations in each country or meet international market reduction of residue requirements, as described by Haviland \& Beers (2012). Screening for non-synthetic insecticides (e.g., plant extracts, essential oils, or other products already used by local organic growers that may be effective against this species) will provide alternative options that could be integrated with the other management practices discussed earlier in the text.

Growers are a key piece for the sustainable management of this pest. All the management strategies discussed herein and in other studies [such as in Cini et al (2012), Asplen et al (2015), Nava et al (2015) and Haye et al (2016)] should be applied by growers with professional supervision, especially if an AW-IPM program should be ever applied. Some recommendations, such as the destruction or sanitization of any other fruit species around the production field, may experience barriers in farm borders when neighborhoods refuse to participate in AW management of this pest, or if native protected vegetation areas are located nearby. Thus, a regulatory disposition coordinating these actions is necessary.

\section{Development of a large-scale (AW-IPM) management program for D. suzukii}

The concept of the AW approach for pest management was introduced by Knipling and Rower (Kogan 1998). However, even before its conceptualization, the AW approach was already used against several invasive pests [e.g., the grafting of all European grapes with American phylloxera-resistant rootstocks; the eradication of the tsetse fly Glossina palpalis Robineau-Desvoiy (Diptera: Glossinidae) from Portugal in 1914; and the fruit fly management programs in the USA, as reported for Ceratitis capitata Wiedemann (Diptera: Tephritidae) in California] (Vreysen et al 2007). In theory, the AW approach must be applied over large geographical areas led by organizations rather than by individual farmers, with a focus on population suppression or, if viable, eradication of the pest (Kogan 1998). Drosophila suzukii possesses bioecological characteristics, such as its high polyphagia, that compromise any eradication programs for this species in regions with high host availability and climate adequacy for the species. Hence, population suppression should be the focus of a management programs in the southern Neotropical region (perhaps in Chile, geographical isolation might be considered), and an AW approach using IPM strategies is likely optimal. However, it is important to note the social concerns about the strategies employed, the willingness of the farmers to collaborate, and the lack of regulatory efforts to prevent consecutive re-invasion of the managed regions, represents high threats associated with any AW-IPM program (Vreysen et al 2007). These factors partially determine the success or failure of these programs (please see Klassen (2005) for a list of examples). Consequently, regulatory provisions from governmental agencies coordinating actions, such as the removal of alternative hosts from the proximities of the cropping fields, are essential (Vreysen et al 2007).

Below, we provide a draft proposal of step-by-step actions to be taken to develop an AW-IPM program to suppress the $D$. suzukii population not only farm-by-farm but in a wide area, following the proposal by Vreysen et al (2007).

Basic research. The core of any AW-IPM program is the development of new tools and technologies. According to Vreysen et al (2007), successful programs were achieved when an independent institution was responsible for planning and developing the new tools and methods for the program. Failure in this first step, although it is not noticed during this first program phase, will compromise the entire program.

As a very first point, it is important to understand the genetic "blue print" of the pest species, $D$. suzukii, within the regions the AW-IPM program to be applied. For this purpose, molecular tools are available (Hoy 2013) and make it possible to analyze the genetic diversity and prevent future control failures as a result of this diversity. In association, it is important to access the differential responses of local pest populations to xenobiotics such as insecticides, elucidating and preventing any possible resistance selection. Other techniques that might be developed for use in an AW-IPM program for $D$. suzukii involve the reduction of reproduction, either by using sterile insect techniques (Klassen 2005), as is currently being used for mosquito control in Piracicaba city, SP, Brazil (Waltz 2016), or by using Wolbachia strains that would cause cytoplasmic incompatibility, as is being developed for Bemisia tabaci Gennadius (Hemiptera: Aleyrodidae) (Zhou \& Li 2016).

As advocated by the IPM component of the program, other components must be used in association to achieve a successful program (Kogan 1998). The study of the local biodiversity and development of mass rearing techniques for use in augmentative biological programs with endemic 
promising parasitoids species is fundamental (Wollmann et al 2016, Andreazza et al 2017b). Additionally, the conservation of this species in the field should be considered, leading to the need for selectivity studies of products that could be used against $D$. suzukii.

Modeling and developing new methods. Modeling tools can be used to understand population fluctuations in time and space and to predict the potential pest distribution and/or spreading capacity (Vreysen et al 2007). For example, Benito et al (2016) and dos Santos et al (2017) used the climatic index (Climex) and algorithms, respectively, to predict the potential spread of $D$. suzukii in the southern Neotropical region. In addition to modeling, the development of new simple tools, such as a year-round calendar of available hosts, strongly helps to coordinate the management efforts over time. This calendar also helps researchers or pest advisors to identify gaps or bottlenecks in host availability that may be used to develop new management strategies. Thus, we proposed an annual calendar (Fig 3) comprising the known $D$. suzukii main hosts cultivated in the southernmost region of Brazil. Due to the large area of the southern Neotropical region and different production models, the production calendar greatly varied from and should be adapted into each macro region and updated with information provided from future studies conducted in each location.

Feasibility studies and regulation. In addition to the development of new tools and technologies by basic research, collecting data for cost/benefit analyses will be fundamental for the success of the WA-IPM program (Vreysen et al 2007). Among these investigations, the continuous collection of data regarding $D$. suzukii fluctuations throughout the year in fields and natural habitats, as well as the estimation of all possible economic losses caused by these fly infestations, is noteworthy. With these data, feasibility studies can better plan and later monitor the efficiency of the program. Additionally, the development of a logistical design of cultivation and IPM component rotation based on both the crop phenology and the pest life-history traits (such as the early proposed crop calendar) is also essential, and a pilot study may be used (Vreysen et al 2007).

Well-conducted feasibility studies will help to convince all stakeholders about the program needs, requirements and fund raising. It will also identify logistical challenges such as the availability of resources and infrastructure for an operational program, enabling planning to mitigate all these challenges. Thus, political and regulatory efforts by governmental agencies are necessary (Hendrichs et al 2007).

The regulatory framework of products and technologies to be used in a potential D. suzukii AW-IPM program will aid not only the operability of the program but also the international trade market. Recently, the first patent deposit of flavoring esters for $D$. suzukii control in the Neotropical region represents an example of non-toxic environmentally friendly products being regulated in the southern Neotropical region (Garcia et al 2016). The development and regulation of postharvest treatments that guaranty pest-free products, such as ionizing radiation, which meets International Plant Protection Conventions provisions, will provide additional tools to prevent continuous reinfestations of $D$. suzukii in managed areas.

Pilot and operational AW-IPM programs. The pilot trials are very effective for identifying program failures and improvement needs for a completely operational AW-IPM program to be successfully implemented. Thus, in addition to testing technologies commonly used in field-by-field IPM, the testing of technologies more related to the AW approach will be required (e.g., pilot mass-rearing facilities of sterile flies, and/or parasitoids, pilot field release of such species, intensive training of staff to work in these facilities). An example is the program that is already being developed in the south of Brazil to rear and mass release sterile fruit fly species and parasitoids (Embrapa 2016).

After all the technologies have been tested and validated under field pilot conditions, the program can be implemented. Great attention must be used in this phase due to the use of a large-scale area and resources. The political, regulatory and commitment off all parts is essential to guarantee success. One remarkable recent example of an operational AWIPM program that does not rely on mass rearing and release of insects (which can be the most challenging part of developing and implementing an AW-IPM program) is the eradication of the boll weevil in the USA. This program has been very successful and is based mostly on intensive monitoring and detection tools, integrated with a few other control tools (Hendrichs et al 2007), and it serves as an example that with the commitment of all parts (from research, government, growers, industries and market), a fully operational AWIPM program for $D$. suzukii will be viable in the future.

\section{Final Considerations}

The current panorama of $D$. suzukii infestation in the southern Neotropical region is still underinvestigated. Most empirical studies (published studies, excluding notes of occurrence) were developed only in Brazil by a few research groups in an attempt to validate international information for local realities, demonstrating a delay in actions against this alien pest invasion. As discussed in this forum, intensive and integrative studies, such as $i-$ monitoring the pest presence and field fluctuations, ii-identifying and classifying the host status of cultivated and non-cultivated fruit species, iiiidentifying and improving any source of natural in-field 
biological control, and finally iv-discussing, testing, and developing new tools and management strategies to cope with this highly mobile pest species using an AW-IPM approach system are essential and needed. The integration of the research community with growers, especially the collaboration of the governmental regulating agencies for the establishment of a collaborative regulatory framework, and the full commitment of funding agencies in providing the necessary resources for the development of science related to this highly damaging invasive species will mitigate economic losses and generate positive profit for the national and international economies of the affected countries.

A large amount of very diverse information was discussed in this forum. The authors hope that their goal of raising the attention of all stakeholders regarding the urgent needs of a cooperative discussion about $D$. suzukii invasion has been accomplished. It is very important to search for answers about what can be done to mitigate this problem in an efficient, low-cost, environmentally friendly and sustainable way. Thus, we advocate that government and industry should focus more attention on collaborative efforts, such as the promotion of regional, national and international meetings involving the various interested parts.

Acknowledgements Grants from the CAPES Foundation, the National Council of Scientific and Technological Development (CNPq), the Minas Gerais State Foundation for Research Aid (FAPEMIG), and the Empresa Brasileira de Pesquisa Agropecuaria (EMBRAPA) supported this work.

\section{References}

Alexandre BG (2016) Avaliação das assembleias de Drosophilidae (Insecta, Diptera) em área de restinga no município de Torres-RS. BSc, Universidade Federal do Rio Grande do Sul, Porto Alegre, Brasil, p 48

Andreazza F, Bernardi D, Botton M, Nava DE (2015) Índice de infestação natural de Drosophila suzukii e Zaprionus indianus (Diptera: Drosophilidae) em frutíferas nativas no município de pelotas. In: XXIV Congresso de Iniciação Científica e XVII Encontro da PósGraduação, 2015, Pelotas. Anais... Pelotas: Universidade Federal de Pelotas, Pelotas, Rio Grande do Sul, Brasil, $4 p$

Andreazza F, Haddi K, Oliveira EE, Ferreira JAM (2016a) Drosophila suzukii (Diptera: Drosophilidae) arrives at Minas Gerais state, a main strawberry production region in Brazil. Fla Entomol 99:796-798

Andreazza F, Bernardi D, Botton M, Nava DE (2017a) Drosophila suzukii (Matsumura) (Diptera: Drosophilidae) in peaches: is it a problem? Sci Agric 74:489-491

Andreazza F, Bernardi D, Nava DE, Botton M, Costa VA (2017b) Inimiga Parasitada. Cultivar HF 102:20-23

Andreazza F, Bernardi D, Marangon RB, Scheunemann T, Botton $M$, Nava DE (2016b) Técnica de Criação de Drosophila suzukii (Matsumura, 1931) (Diptera: Drosophilidae) em Dieta Artificial. Embrapa Clima Temperado, Pelotas, Rio grande do Sul. 23p. (Série Boletim de Pesquisa e Desenvolvimento 240)

Andreazza F, Bernardi D, Baronio CA, Pasinato J, Nava DE, Botton M (2017c) Toxicities and effects of insecticidal toxic baits to control
Drosophila suzukii and Zaprionus indianus (Diptera: Drosophilidae). Pest Manag Sci 73:146-152

Andreazza F, Baronio CA, Botton M, Valgas RA, Ritschel PS, Maia JDG, Nava DE (2016c) Suscetibilidade de bagas de genótipos de videira pela infestação por Drosophila suzukii (Diptera: Drosophilidae). Pesqui Agropecu Bras 51:599-606

Antunes LEC, Gonçalves ED, Ristow NC, Carpenedo S, Trevisan R (2008) Fenologia, produção e qualidade de frutos de mirtilo. Pesqui Agropecu Brasil 43:1011-1015

Ashburner M, Golic KG, Hawley RS (2005) Drosophila: a laboratory handbook. Cold Spring Harbor Laboratory Press, New York, p 1409

Asplen MK, Anfora G, Biondi A, Choi D-S, Chu D, Daane KM, Gibert P, Gutierrez AP, Hoelmer KA, Hutchison WD, Isaacs R, Jiang Z-L, Kárpáti Z, Kimura MT, Pascual M, Philips CR, Plantamp C, Ponti L, Vétek G, Vogt H, Walton VM, Yu Y, Zappalà L, Desneux N (2015) Invasion biology of spotted wing Drosophila (Drosophila suzukii): a global perspective and future priorities. J Pest Sci 88:469-494

Azambuja AC (2009) Demografia e Fenologia Reprodutiva de Butia capitata (Mart.) Becc.(Arecaceae) em Arambaré, Rio Grande do Sul. MSc Thesis, Universidade Federal do Rio Grande do Sul, Porto Alegre, Brasil, p 47

Azevedo FQ (2010) Perfil vitivinícola, fenologia, qualidade e produção de uvas americanas e híbrida em Pelotas-RS. Universidade Federal de Pelotas, Pelotas, Brasil, MSc Thesis, p 103

Beers EH, Van Steenwyk RA, Shearer PW, Coates WW, Grant JA (2011) Developing Drosophila suzukii management programs for sweet cherry in the western United States. Pest Manag Sci 67:1386-1395

Bellamy DE, Sisterson MS, Walse SS (2013) Quantifying host potentials: indexing postharvest fresh fruits for spotted wing drosophila, Drosophila suzukii. PLoS One 8:e61227

Benedict MQ, Levine RS, Hawley WA, Lounibos LP (2007) Spread of the Tiger: global risk of invasion by the mosquito Aedes albopictus. Vector-Borne and Zoonotic Dis 7:76-85

Benito NP, Lopes-da-Silva M, Santos RSS (2016) Potential spread and economic impact of invasive Drosophila suzukii in Brazil. Pesqui Agropecu Bras 51:571-578

Bernardi D, Andreazza F, Botton M, Baronio CA, Nava DE (2017) Susceptibility and interactions of Drosophila suzukii and Zaprionus indianus (Diptera: Drosophilidae) in damaging strawberry. Neotrop Entomol 46:1-7

Bianchi VJ, Junior JC, Fachinello J, Strelow E (1998) Maturação de figos cv. Roxo de Valinhos fora do período normal de colheita Revis Bras de Agrocienc 4:218-221

Bisognin M, Nava DE, Diez-Rodríguez GI, Valgas RA, Garcia MS, Krolow AC, Antunes LEC (2015) Development of Anastrepha fraterculus (Diptera: Tephritidae) related to the phenology of blueberry, blackberry, strawberry guava, and Surinam cherry fruits. J Econ Entomol 108:192-200

Bitner-Mathé BC, Victorino J, Faria FS (2014) Drosophila suzukii has been found in tropical Atlantic rainforest in southeastern Brazil. Dros Inf Serv 97:136-137

Borba RS, Foppa F, Frare JB (2016b) Ocorrência de Drosophila suzukii (Matsumura, 1931) (Diptera, Drosophilidae) em pêssego. p 528 In: XXVI Congresso Brasileiro de Entomologia, 2016, Maceió. Anais... Brasilia: Embrapa, Brasilia, DF, Brazil, 670p

Borba RS, Foppa F, Bortoncello A, Secretti T (2016a) Infestação de Drosophila suzukii (Matsumura, 1931) (Diptera, Drosophilidae) em frutos de pêssego. p 359. In: XXVI Congresso Brasileiro de Entomologia, 2016, Maceió. Anais...Brasilia: Embrapa, Brasilia, DF, Brazil, 670p

Bruck DJ, Bolda M, Tanigoshi L, Klick J, Kleiber J, DeFrancesco J, Gerdeman B, Spitler H (2011) Laboratory and field comparisons of insecticides to reduce infestation of Drosophila suzukii in berry crops. Pest Manag Sci 67:1375-1385

Burrack HJ, Fernandez GE, Spivey T, Kraus DA (2013) Variation in selection and utilization of host crops in the field and laboratory by 
Drosophila suzukii Matsumara (Diptera: Drosophilidae), an invasive frugivore. Pest Manag Sci 69:1173-1180

Calabria G, Máca J, Bächli G, Serra L, Pascual M (2012) First records of the potential pest species Drosophila suzukii (Diptera: Drosophilidae) in Europe. J Appl Entomol 136:139-147

Cardoso LS, Palhano WC, Martignago J, Bellini JS, Seibert E, Streck L (2012) Avaliação das características fenológicas e de produção de seleções de nespereiras. Revista Técnico Científica do IFSC 3:765

Carvalho SF (2013) Produção, qualidade e conservação pós-colheita de frutas de diferentes cultivares de morangueiro nas condições edafoclimáticas de Pelotas-RS. Universidade Federal de Pelotas, Pelotas, Brasil, MSc Thesis, p 102

Castro LAS (2008) Monitoramentos realizados no cultivo da ameixeira na região sul do Brasil visando adaptação das recomendações técnicas. Embrapa Clima Temperado, Pelotas, Rio grande do Sul. 39p. (Série Documentos 235)

Chabert S, Allemand R, Poyet M, Eslin P, Gibert P (2012) Ability of European parasitoids (Hymenoptera) to control a new invasive Asiatic pest, Drosophila suzukii. Biol Control 63:40-47

Cichón LI, Lago JD, Garrido SA (2015) Primera detección de Drosophila suzukii (Matsumura, 1939) (Diptera: Drosophilidae) en frambuesas del Valle de Río Negro, Argentina. In: Marti D (ed) IX Congreso Argentino de Entomología Posadas: libro de resúmenes. Universidad Nacional de Misiones, Posadas, p 270

Cini A, loriatti C, Anfora G (2012) A review of the invasion of Drosophila suzukii in Europe and a draft research agenda for integrated pest management. Bull Insectol 65:149-160

Cini A, Anfora G, Escudero-Colomar LA, Grassi A, Santosuosso U, Seljak G, Papini A (2014) Tracking the invasion of the alien fruit pest Drosophila suzukii in Europe. J Pest Sci 87:559-566

Commar LS, Galego LGC, Ceron CR, Carareto CMA (2012) Taxonomic and evolutionary analysis of Zaprionus indianus and its colonization of Palearctic and Neotropical regions. Genet Mol Biol 35:395-406

Cuthbertson AG, Collins DA, Blackburn LF, Audsley N, Bell HA (2014) Preliminary screening of potential control products against Drosophila suzukii. Insects 5:488-498

Daane KM, Wang X-G, Biondi A, Miller B, Miller JC, Riedl H, Shearer PW, Guerrieri E, Giorgini $M$, Buffington $M$, van Achterberg $K$, Song $Y$, Kang T, Yi H, Jung C, Lee DW, Chung B-K, Hoelmer KA, Walton VM (2016) First exploration of parasitoids of Drosophila suzukii in South Korea as potential classical biological agents. J Pest Sci 89:823-835

Deprá M, Poppe JL, Schmitz HJ, De Toni DC, Valente VLS (2014) The first records of the invasive pest Drosophila suzukii in the south American continent. J Pest Sci 87:379-383

Desneux N, Luna MG, Guillemaud T, Urbaneja A (2011) The invasive south American tomato pinworm, Tuta absoluta, continues to spread in Afro-Eurasia and beyond: the new threat to tomato world production. J Pest Sci 84:403-408

Diepenbrock LM, Swoboda-Bhattarai KA, Burrack HJ (2016) Ovipositional preference, fidelity, and fitness of Drosophila suzukii in a co-occurring crop and non-crop host system. J Pest Sci 89:761-769

Dreves AJ, Walton VM, Fisher G (2009) A new pest attacking healthy ripening fruit in Oregon, spotted wing Drosophila: Drosophila suzukii (Matsumura). EM 8991 October 2009. Oregon State University, extension service

Embrapa (2016) Ministro da Agricultura conhece Centro Moscasul na Embrapa Uva e Vinho. https://www.embrapa.br/en/busca-denoticias/-/noticia/15312389/ministro-da-agricultura-conhece-centromoscasul-na-embrapa-uva-e-vinho Accessed 12 Feb 2017

Emiljanowicz LM, Ryan GD, Langille A, Newman J (2014) Development, reproductive output and population growth of the fruit fly pest Drosophila suzukii (Diptera: Drosophilidae) on artificial diet. J Econ Entomol 107:1392-1398

Fartyal RS, Sarswat M, Lhamo N, Sati P, Asha L (2014) Records of Zaprionus indianus and Drosophila suzukii indicus as invasive fruit pests from mid valley region of Garhwal Uttarakhand, India. Dros Info Serv 97:119-123

Gabarra R, Riudavets J, Rodríguez GA, Pujade-Villar J, Arnó J (2015) Prospects for the biological control of Drosophila suzukii. BioControl 60:331-339

Garcia FRM, Teixeira CM, Pacheco BS, Pereira CMP, Silva CC, Collares TV inventors (2016) Uso de ésteres flavorizantes no controle de Drosophila suzukii. Brazil, patent

Geisler FCS, Santos J, Holdefer DR, Garcia FRM (2015) Primeiro registro de Drosophila suzukii (Matsumura, 1931)(Diptera: Drosophilidae) para o estado do Paraná, Brasil e de novos hospedeiros. Revista de Ciências Ambientais 9:125-129

González G, Mary AL, Goñi B (2015) Drosophila suzukii (Matsumura) found in Uruguay. Dros Info Serv 98:103-107

González G, Lucía Mary AL, Scatoni B, Lorenzo ME, Vignale B, Goñi B (2014) Drosophila suzukii (Arthropoda, Insecta, Diptera) en Uruguay. In: III Congreso Uruguayo de Zoología. Facultá de Ciencias, Montevideo pp 207

Grassi A, Palmieri L, Giongo L (2009) Drosophila (Sophophora) suzukii (Matsumura). New pest of small fruit crops in Trentino. Terra Trentina 10:19-23

Guerrieri E, Giorgini M, Cascone P, Carpenito S, van Achterberg C (2016) Species diversity in the parasitoid genus Asobara (Hymenoptera: Braconidae) from the native area of the fruit fly pest Drosophila suzukii (Diptera: Drosophilidae). PLoS One 11:e0147382

Hauser M (2011) A historic account of the invasion of Drosophila suzukii (Matsumura) (Diptera: Drosophilidae) in the continental United States, with remarks on their identification. Pest Manag Sci 67: 1352-1357

Haviland DR, Beers EH (2012) Chemical control programs for Drosophila suzukii that comply with international limitations on pesticide residues for exported sweet cherries. J Integr Pest Manage 3:1-6

Haye T, Girod P, Cuthbertson AGS, Wang XG, Daane KM, Hoelmer KA, Baroffio C, Zhang JP, Desneux N (2016) Current SWD IPM tactics and their practical implementation in fruit crops across different regions around the world. J Pest Sci 89:643-651

Hendrichs J, Kenmore P, Robinson A, Vreysen MJ (2007) Area-wide integrated pest management (AW-IPM): principles, practice and prospects in: Vreysen MJ, Robinson A, Hendrichs J (eds.) area-wide control of insect pests: from research to field implementation. Springer, Netherlands, pp 3-33

Hoy MA (2013) Insect molecular genetics: an introduction to principles and applications. Academic Press, San Diego, p 736

Ioriatti C, Boselli M, Caruso S, Galassi T, Gottardello A, Grassi A, Tonina L, Vaccari G, Mori N (2015) Approccio integrato per la difesa dalla Drosophila suzukii. Frutticoltura 4:32-36

Jackson DS, Lee BG (1985) Medfly in California 1980-1982. Bull Entomol Soc Am 31:29-37

Joshi NK, Biddinger DJ, Demchak K, Deppen A (2014) First report of Zaprionus indianus (Diptera: Drosophilidae) in commercial fruits and vegetables in Pennsylvania. J Insect Sci 14:1-4

Kenis M, Tonina L, Eschen R, van der Sluis B, Sancassani M, Mori N, Haye $\mathrm{T}$, Helsen $\mathrm{H}$ (2016) Non-crop plants used as hosts by Drosophila suzukii in Europe. J Pest Sci 89:735-748

Klassen W (2005) Area-wide integrated pest management and the sterile insect technique. In: Dyck VA, Hendrichs J, Robinson AS (eds) Sterile insect technique: principles and practice in area-wide integrated pest management. Springer Netherlands, Dordrecht, pp 39-68

Kogan M (1998) Integrated pest management: historical perspectives and contemporary developments. Annu Rev Entomol 43:243-270

Kriticos DJ, Ota N, Hutchison WD, Beddow J, Walsh T, Tay WT, Borchert DM, Paula-Moreas SV, Czepak C, Zalucki MP (2015) The potential distribution of invading Helicoverpa armigera in North America: is it just a matter of time? PLoS One 10:e0119618 
Lasa R, Tadeo E (2015) Invasive drosophilid pests Drosophila suzukii and Zaprionus indianus (Diptera: Drosophilidae) in Veracruz, Mexico. Fla Entomol 98:987-988

Lee JC, Dreves AJ, Cave AM, Kawai S, Isaacs R, Miller JC, Van Timmeren S, Bruck DJ (2015) Infestation of wild and ornamental noncrop fruits by Drosophila suzukii (Diptera: Drosophilidae). Ann Entomol Soc Am 108: 117-129

Lue C-H, Mottern JL, Walsh GC, Buffington ML (2017) New record for the invasive spotted wing drosophila, Drosophila suzukii (Matsumura, 1931) (Diptera: Drosophilidae) in Anillaco, Western Argentina. Proc Entomol Soc Wash 119:146-150

Madail JC, Raseira MCB (2008) Aspectos da produção e mercado do pêssego no Brasil. Embrapa Clima Temperado, Pelotas, Rio grande do Sul. 14p. (Circular técnica 80)

Malavasi A, Zucchi RA (2000) Moscas-das-frutas de importância econômica no Brasil: conhecimento básico e aplicado. Holos, Ribeirão Preto, p 325

MAPA (2016) Ministério da Agricultura Pecuária e Abastecimento, Brasilia. AGROFIT: Sistema de Agrotóxicos Fitossanitários-MAPA/ CGAF/DFIA/DAS. http://agrofitagriculturagovbr/agrofit_cons/ principal_agrofit_cons Accessed (27 Feb 2017)

Medina-Muñoz MC, Lucero X, Severino C, Cabrera N, Olmedo D, Del Pino F, Alvarez E, Jara C, Godoy-Herrera R (2015) Drosophila suzukii arrived in Chile. Dros Info Serv 98:75

MGAP-ServiciosAgrícolas (2017) Consulta de Productos Fitosanitarios. https://wwwmgapgubuy/profit/wwplagaaspx Accessed (18 Feb 2017)

Müller FA, Nava DE (2014) Primeiro relato de Drosophila suzukii (Diptera: Drosophilidae) em frutos de araçá e pitanga em municípios da região sul do Rio Grande do Sul, Brasil. In: XXV Congresso Brasileiro de Entomologia. SEB, Goiânia, $p 1$

Nava DE, Botton M, Bernardi D, Andreazza F, Baronio CA (2015) Bioecologia, monitoramento e controle de Drosophila suzukii na cultura do morangueiro. Embrapa Clima Temperado, Pelotas, Rio Grande do Sul, 28p. (Série documentos 398)

Nunes AM, Schlesener DCH, Souza DS, Neumann AM, Garcia FRM (2014) Primeiros registros de Drosophila suzukii (Diptera: Drosophilidae) em agroecossistemas na metade sul do Rio Grande do Sul. In: XXV Congresso Brasileiro de Entomologia. SEB, Goiânia, $p 1$

Oliveira AS, Amaral Neto JAB, Santos RSS (2015) Primeiro registro de Drosophila suzukii (Diptera: Drosophilidae) em pomar de macieira em Vacaria- Rio Grande do Sul. In: XIII Encontro de Iniciação Científica e IX Encontro de Pós-Graduandos da Embrapa Uva e Vinho. Embrapa Uva e Vinho, Bento Gonçalves, p 44

Padilha AC, Arioli CJ, Nunes MZ, Rosa JM, Rosa TD, Mafra-Neto A, Borges $\mathrm{R}$, Bittencourt MM, Botton M (2016) Avaliação de atrativos alimentares na captura de Drosophila suzukii na cultura da videira, p. 589. In: XXVI Congresso Brasileiro de Entomologia, 2016, Maceió. Anais...Brasilia: Embrapa, Brasilia, DF, Brazil, 670p

Paula MA, Lopes PHS, Tidon R (2014) First record of Drosophila suzukii in the Brazilian savanna. Dros Info Serv 97:113-115

Perrings C, Williamson M, Barbier E, Delfino D, Dalmazzone S, Shogren J, Simmons P, Watkinson A (2002) Biological invasion risks and the public good: an economic perspective. Conserv Ecol 6:7

Poyet $M$, Eslin $P$, Héraude $M$, Le Roux V, Prévost $G$, Gibert $P$, Chabrerie $O$ (2014) Invasive host for invasive pest: when the Asiatic cherry fly (Drosophila suzukii) meets the American black cherry (Prunus serotina) in Europe. Agricul For Entomol 16:251-259

Raga A, Souza Filho M, Sato M (2003) Eficiência de protetores de ostíolo do figo sobre a infestação da mosca Zaprionus indianus (Gupta)(Diptera: Drosophilidae) no campo. Arquivos do Instituto Biológico 70:287-289

Ramírez MF, Wildemann B, Bizzo LEM, Silva NM, De Toni DC (2015) Levantamiento taxonómico preliminar de drosofílidos (Diptera; Drosophilidae) en tres unidades de conservación del estado de Santa Catarina, Brasil. In: Marti D (ed) IX Congreso Argentino de Entomología: libro de resúmenes. Universidad Nacional de Misiones, Posadas, p 197
Raseira MCB, Gonçalves ED, Trevisan R, Antunes LEC (2004) Aspectos técnicos da cultura da framboeseira. Embrapa Clima Temperado, Pelotas, Brazil, p 22 (Série Documentos 120)

Renkema J, Miller M, Fraser H, Légaré J-P, Hallett R (2013) First records of Zaprionus indianus Gupta (Diptera: Drosophilidae) from commercial fruit fields in Ontario and Quebec, Canada. J Entomol Soc Ont 144:125-130

SAG (2017) Lista de plaguicidas con autorización vigente. http:// wwwsagcl/ambitos-de-accion/evaluacion-y-autorizacion-deplaguicidas/1367/registros Accessed (08 Feb 2017)

Santadino MV, Riquelme Virgala MB, Ansa MA, Bruno M, Di Silvestro G, Lunazzi EG (2015) Primer registro de Drosophila suzukii (Diptera: Drosophilidae) asociado al cultivo de arándanos (Vaccinium spp.) de Argentina. Revista de la Sociedad Entomológica Argentina 74:183-185

dos Santos LA, Mendes MF, Krüger AP, Blauth ML, Gottschalk MS, Garcia FRM (2017) Global potential distribution of Drosophila suzukii (Diptera, Drosophilidae). PLoS One 12:e0174318

Santos RSS (2014) Ocorrência de Drosophila suzukii (Matsumura, 1931) (Diptera: Drosophilidae) Atacando Frutos de Morango no Brasil. Embrapa, Bento Gonçalves, Brazil, p 4 (Comunicado Técnico 159)

Schlesener DCH, Nunes AM, Cordeiro J, Gottschalk MS, Garcia FRM (2014) Mosca-da-cereja (Drosophila suzukii): uma nova ameaça para a fruticultura brasileira. Cultivar HF 12:6-8

Schlesener DCH, Wollmann J, Nunes AM, Cordeiro J, Gottschalk MS, Garcia FRM (2015) Drosophila suzukii: nova praga para a fruticultura brasileira. O Biológico 77:47-54

Singer M (2017) The spread of Zika and the potential for global arbovirus syndemics. Global Public Health 12:1-18

Souza DS, Valer FB, Cordeiro J, Gottschalk MS (2013) Primeiro registro de Drosophila suzukii no Brasil. In: XXII Congresso de Iniciação Científica e XV Encontro da Pós-Graduação, 2013, Pelotas. Anais... Pelotas: Universidade Federal dePelotas, Pelotas, Rio Grande do Sul, Brazil, $4 \mathrm{p}$

Souza GK, Pikart TG, Oliveira VL, Boff P, Boff MIC (2017) Acca sellowiana (Myrtaceae): a new alternative host for Drosophila suzukii (Diptera: Drosophilidae) in Brazil. Fla Entomol 100:190-191

Tochen S, Dalton DT, Wiman N, Hamm C, Shearer PW, Walton VM (2014) Temperature-related development and population parameters for Drosophila suzukii (Diptera: Drosophilidae) on cherry and blueberry. Environ Entomol 43:501-510

Tochen S, Woltz JM, Dalton DT, Lee JC, Wiman NG, Walton VM (2016) Humidity affects populations of Drosophila suzukii (Diptera: Drosophilidae) in blueberry. J App Entomol 140:47-57

Trottin Y, Paulhiac E, Zicot A, Baffert V, Leyre J, Weydert C, Poyet M, Ris $N$, Gibert P (2014) Experimental studies on Drosophila suzukii in protected strawberry crops: biology of the pest and effectiveness of a parasitoid of pupa in field conditions. Proceeding of the IOBC VIII Workshop on Integrated Soft Fruit Production. Trento, In, pp 26-28

Van Timmeren S, Isaacs R (2013) Control of spotted wing drosophila, Drosophila suzukii, by specific insecticides and by conventional and organic crop protection programs. Crop Prot 54:126-133

Vilela CR, Mori L (2014) The invasive spotted-wing Drosophila (Diptera, Drosophilidae) has been found in the city of São Paulo (Brazil). Rev Bras Entomol 58:371-375

Vreysen MJ, Robinson A, Hendrichs J (2007) Area-wide control of insect pests: from research to field implementation. Springer, Netherlands, p 789

Walsh DB, Bolda MP, Goodhue RE, Dreves AJ, Lee J, Bruck DJ, Walton VM, O'Neal SD, Zalom FG (2011) Drosophila suzukii (Diptera: Drosophilidae): invasive pest of ripening soft fruit expanding its geographic range and damage potential. J Integr Pest Manage 2:1-7

Waltz E (2016) GM mosquitoes fire first salvo against Zika virus. Nat Biotech 34:221-222

Wang X-G, Kaçar G, Biondi A, Daane KM (2016) Life-history and host preference of Trichopria drosophilae, a pupal parasitoid of spotted wing drosophila. BioControl 61:387-397 
Wollmann J, Schlesener DCH, Ferreira MS, Garcia MS, Costa VA, Garcia FRM (2016) Parasitoids of Drosophilidae with potential for parasitism on Drosophila suzukii in Brazil. Dros Info Serv 99:38-42
Zhou X-F, Li Z-X (2016) Establishment of the cytoplasmic incompatibilityinducing Wolbachia strain wMel in an important agricultural pest insect. Sci Rep 6:39200 